\title{
Organoleptic Evaluation of Dried Colocasia Leaves (Colocasia esculenta) Powder Incorporated in Kharapara and Puri
}

\author{
Pratibha Thombare* and Farooqui H. Farzana \\ Department of Food Science and Nutrition, College of Community Science, VNMKV \\ Parbhani-431402, Maharashtra, India \\ *Corresponding author
}

\begin{tabular}{|l|}
\hline Ke y w o r d s \\
Organoleptic, \\
Incorporated, Colocasia \\
leaves powder
\end{tabular}

"Colocasia leaves", (also known as Taro) in its dry form has been known as a good source of Calcium. Scientifically known as Colocasia esculenta and belongs to Araceae. The present study was conducted on "Organoleptic evaluation of dried Colocasia leaves powder incorporated in "kharapar and Puri". In the present study dried Colocasia leaves powder was incorporated in different ratios in "Kharapara and Puri $(0 \%, 4 \%, 5 \%, 6 \%$ and 7\%). A panel of 15 members was selected through Triangle Test for evaluation of the incorporated recipes. 9Point Hedonic Rating Scale and Composite Scoring test was used for evaluation. Mean score, S.D, and t-value were used for statistical analysis of the scores of acceptability trials of all recipes. On the basis of scores four most acceptable recipes from dried colocasia leaves powder was incorporated in Kharapara (6\%) and Puri (6\%) all the samples were selected and their nutritive value was calculated. The nutrient calculation showed a good increase in calcium with the incorporation of dried colocasia leaves powder as compared to standard recipe. It was concluded that dried colocasia leaves powder could be successfully incorporated in recipes as it is a very good source of calcium and could be very beneficial for women having calcium deficiency.

\section{Introduction}

Colocasia leaves (Colocasai esculenta) a species of Cocoyam is an herbaceous perennial plant belonging to the Aracease family (Ndabikunze, 2011). This plant is probably originates from the tropical region between India and Indonesia (Matthews, 2004) and has been grown in the South Pacific for hundreds of years (FAO, 1992). Taro produces edible corms (Chay-Prove and Goebel, 2004) and the leaves are also used as a vegetable (Aregheore and Perera, 2003).
Colocasia leaves are of great medicinal value and are included in many ayurvedic preparations. Plants are rich source of bioactive phytochemicals, which can occur in different forms, such as proteins or peptides, carotenoids, polyphenols, isoflavones and sterols (Abuajah et al., 2015). Such bioactive compounds are used for defense, exerting pharmacological or toxicological effects in animals and humans (Patricia et al., 2015). Colocasia leaves have been reported to be rich in nutrients, including minerals such as calcium, phosphorus, iron, and vitamins like 
vitamin $\mathrm{C}$, thiamine, riboflavin and niacin. High level of dietary fibres in colocasia are also advantageous for their active role in the regulation of intestinal transit, increasing dietary bulk, faeces consistency due to their ability to absorb water (Melese and Negussie, 2015).

Colocasia leaves are usually consumed by humans after heat treatments, such as boiling, steaming, stewing, frying and pressure cooking. These methods are found to be affective in improving digestibility, increasing bioavailability and also minimizing foodborne diseases. Through boiling also reduce the nutritional value of food crops arising from significant losses and changes in major nutrients during cooking (Lewu et al., 2009).

Colocasia leaves are consumed by after cooking, either by boiling, blanching, steaming, stewing, frying or pressure cooking. These methods are found to be effective in improving digestibility, increasing nutrient availability and also minimizing food-borne diseases (Fellows, 1990). Though, boiling can help to reduce the oxalate content in the leaves of this species, it may also reduce the nutritional value of food crops arising from significant losses and changes in major nutrients during cooking (Lewu et al., 2009).

Soluble oxalates may be lost by leaching during boiling but they will be retained in the leaves during baking. It is also possible that during baking soluble oxalates may leach from the wrapping leaves into the food being cooked. Boiling the colocasia leaves resulted in a $36 \%$ loss of soluble oxalates, while the insoluble oxalate content of baked tissue was very similar to the raw tissue. Soaking the raw leaves in water for 30 min marginally reduces the soluble oxalate content by leaching into the tap water, while soaking for $18 \mathrm{hrs}$ is much more effective as $26 \%$ of soluble oxalate is leached into the tap water. The mean insoluble oxalate content of the soaked leaves (168.35 $\mathrm{mg} / 100 \mathrm{~g}$ ) was very similar to the insoluble oxalate content of the raw tissue (Savage G. P. and Dubois 2006).

The leaves of colocasia are very easily digestible, since they are rich in dietary fiber, they do a great help to the digestive system. The fibre in them increases the stools, bulkiness and normalizes the bowel movements. It prevents some digestive problem like IBS (Irritable Bowel Syndrome) and constipation. It reduces the risk of colon cancer. The leaves of colocasia have enormous amounts of vitamin $\mathrm{A}$, which is required to support different body functions even including eyes. It prevents different eye disorders like myopia, blindness and cataract.

The ash content ranges from 3.54 to 7.78 per cent (Nijintang et al., 2007). Colocasia is a good source of minerals including iron (8.66$10.8 \mathrm{mg} / 100 \mathrm{gm})$, calcium $(31-132 \mathrm{mg} / 100 \mathrm{~g})$, sodium (82-1521.34mg/100g), magnesium (118-415.07mg/100g), phosphorus (72.21$340 \mathrm{mg} / 100 \mathrm{~g})$, zinc $(2.63 \mathrm{mg} / 100 \mathrm{~g})$, copper $(1.04 \mathrm{mg} / 100 \mathrm{~g})$ and an excellent source of potassium (2271-4276.06mg/100g). High potassium to sodium ratio of food recommended for patient with high blood pressure (Melese and Negussie, 2015)

Colocasia leaves are a good source of vitamin folate. Iron is one of the indispensable minerals because it plays a very important role in the development of RBCs and in the transportation of oxygen to various body parts. People, who are anemic, need to consume colocasia on a daily basis, as it not only fulfills the iron deficiency but also avoids fatigue, weakness, and tiredness.

\section{Materials and Methods}

The colocasia leaves were purchased, cleaned and washed with water. For the preparation of 
products with incorporation of dry colocasia leaves powder, the leaves were blanched, dried, powdered with grinder and sieved. This powder was used for preparation of products. 4 recipes with 4 variations were prepared by dried colocasia leaves powder. The basic recipe was prepared for each value added product. Colocasia powder was stored in air tight container for development of recipes and chemical analysis.

Colocasia kharapara and colocasia puri were prepared in five variations with powdered colocasia leaves. Variation one was basic recipe which was prepared without incorporation of dry colocasia leaves powder and used as basic. Variations II to $\mathrm{V}$ were experimental variations with varying levels of incorporation of dry colocasia leaves powder.

The organoleptic evaluation of prepared food products was conducted to find out the maximum level of incorporation of dried colocasia leaves powder in the selected food products (Amerine et al., 1965).

The sensory threshold test was carried out on 20 members to select panel members. Different solutions of sugar and salt with different concentrations for threshold test were prepared as described by Ranganna (1979) and the members were requested to evaluate the solutions for strength of different tastes. Considering the accuracy in evaluation of taste, 15 panel members were selected out of 20 to act as judges for sensory evaluation of products.

The selected food products were prepared with different levels of incorporation of dried colocsia leaves powder. All the selected panel members were requested to evaluate the developed food products. The judges were requested to score the recipes for different sensory characters namely colour, texture, taste, flavour and overall acceptability by using Five Point Ranking Scale in which point 5 represent excellent, 4 represent very good, 3 represent good, 2 represent fair and 1 represent poor (Amerine et al., 1965). Highly accepted variations were selected for nutritional analysis and shelf life study.

The most accepted variation of all the selected food products was subjected to chemical analysis in the laboratory. Various parameters considered for nutrient analysis were moisture, protein, fat, total minerals, fibre, calcium, iron, zinc, magnesium and copper were estimated.

The proximate composition was carried out as per procedures prescribed by A.O.A.C., (1984) method. Protein was estimated by macro kjeldhal method. Carbohydrate content was computed by Gopalan et al., (1989). The calcium was estimated by EDTA (Ethylene diamine tetra acetic acid) method. The trace elements, Iron, zinc, magnesium, and copper were estimated by atomic absorption spectrophotometer. The analysis was carried out by the sample moisture free.

The collected data was consolidated, tabulated and analysed statistically. The analysis of variance was used for interpreting the differences between different variations for individual sensory characters. The statistical difference with regard to nutrient content of developed products prepared with and without incorporation of dried colocasia was assessed by ' $t$ ' test (Gupta, 2014).

\section{Results and Discussion}

Sensory evaluation of kharapara was well accepted up to 7 per cent level of colocasia leaves powder incorporation. Organoleptic evaluation of products developed with incorporation of colocasia leaves powder indicated that colocasia leaves powder can be successfully incorporated up to 7 per cent in various products. 
Table.1 Organoleptic evaluation scores of colocasia kharapara

\begin{tabular}{|c|c|c|c|c|c|c|}
\hline Variations & $\begin{array}{c}\text { Level of colocasia leaves } \\
\text { incorporation (\%) }\end{array}$ & Colour & Texture & Taste & Flavour & $\begin{array}{c}\text { Overall } \\
\text { acceptability }\end{array}$ \\
\hline Basic & 0 & 4.5 & $\mathbf{4 . 8}$ & 4.7 & 4.7 & 4.2 \\
\hline I & 4 & 4.2 & 4.6 & 4.6 & 4.5 & 4.5 \\
\hline II & 5 & 4.2 & 4.6 & 4.5 & 4.6 & 4.6 \\
\hline III & $\mathbf{6}$ & 4.8 & $\mathbf{4 . 8}$ & 4.5 & 4.5 & $\mathbf{4 . 8}$ \\
\hline IV & 7 & $\mathbf{4 . 9}$ & 3.9 & $\mathbf{4 . 9}$ & $\mathbf{4 . 8}$ & $\mathbf{4 . 8}$ \\
\hline & CD & 0.4 & 0.2 & 0.2 & 0.03 & 0.3 \\
\hline & SE \pm & 0.1 & 0.1 & 0.09 & 0.01 & 0.1 \\
\hline
\end{tabular}

NS: Non significant; *Significant at 5 per cent; **Significant at 1 per cent

Table.2 Organoleptic evaluation scores of colocasia puri

\begin{tabular}{|c|c|c|c|c|c|c|}
\hline Variations & $\begin{array}{c}\text { Level of colocasia leaves } \\
\text { incorporation (\%) }\end{array}$ & Colour & Texture & Taste & Flavour & $\begin{array}{c}\text { Overall } \\
\text { acceptability }\end{array}$ \\
\hline Basic & 0 & 4.4 & 4.3 & 4.4 & 3.6 & 3.6 \\
\hline I & 4 & 3.4 & 3.4 & 4.6 & 4.4 & 4.0 \\
\hline II & 5 & 4.4 & 4.0 & 4.2 & 4.1 & 3.3 \\
\hline III & $\mathbf{6}$ & $\mathbf{5 . 0}$ & $\mathbf{4 . 5}$ & $\mathbf{4 . 9}$ & $\mathbf{4 . 9}$ & $\mathbf{4 . 8}$ \\
\hline IV & 7 & 4.6 & 3.0 & 4.2 & 3.8 & 4.1 \\
\hline & $\mathbf{C D}$ & 0.3 & 0.4 & 0.4 & 0.4 & 0.4 \\
\hline & SE \pm & 0.1 & 0.1 & 0.1 & 0.1 & 0.1 \\
\hline & F-value & $25.3 * *$ & $12.2^{* *}$ & $4.1 * *$ & $11.5 * *$ & $12.3^{* *}$ \\
\hline
\end{tabular}

NS: Non significant; *Significant at 5 per cent; $* *$ Significant at 1 per cent

Table.3 Nutrient content of colocasia kharapara (per 100g)

\begin{tabular}{|l|c|c|c|}
\hline \multicolumn{1}{|c|}{ Nutrients } & Basic & Accepted & \multirow{2}{*}{ ' $t$ ' value } \\
\cline { 1 - 3 } & Mean \pm SD & Mean \pm SD & \\
\hline Moisture (g) & $11.94 \pm 0.34$ & $12.32 \pm 0.54$ & $0.84 \mathrm{NS}$ \\
\hline Protein (g) & $7.74 \pm 0.23$ & $8.54 \pm 0.99$ & $1.11 \mathrm{NS}$ \\
\hline Fat (g) & $12.75 \pm 0.05$ & $13.65 \pm 1.5$ & $0.84 \mathrm{NS}$ \\
\hline Total minerals (g) & $7.65 \pm 2.35$ & $8.02 \pm 0.17$ & $0.22 \mathrm{NS}$ \\
\hline filbre (g) & $2.97 \pm 0.5$ & $3.2 \pm 1.05$ & $0.24 \mathrm{NS}$ \\
\hline Carbohydrates (g) & $68.39 \pm 1.65$ & $65.07 \pm 0.08$ & $2.40 \mathrm{NS}$ \\
\hline Calcium (mg) & $126 \pm 9$ & $218 \pm 8.5$ & $10.51 * *$ \\
\hline Iron (mg) & $6.39 \pm 0.37$ & $6.52 \pm 0.01$ & $0.49 \mathrm{NS}$ \\
\hline Copper (mg) & $1.07 \pm 1.07$ & $1.43 \pm 1$ & $0.34 \mathrm{NS}$ \\
\hline Zinc (mg) & $0.41 \pm 0.003$ & $0.45 \pm 0.007$ & $7.42 * *$ \\
\hline Manganese (mg) & $0.74 \pm 0.1$ & $0.78 \pm 0.23$ & $0.24 \mathrm{NS}$ \\
\hline
\end{tabular}

NS: Non significant; *Significant at 5 per cent; **Significant at 1 per cent 
Table.4 Nutrient content of Colocasia puri (per 100g)

\begin{tabular}{|c|c|c|c|}
\hline \multirow[t]{2}{*}{ Nutrients } & Basic & Accepted & \multirow[t]{2}{*}{ 't' value } \\
\hline & Mean \pm SD & Mean \pm SD & \\
\hline Moisture (g) & $19.9 \pm 0.98$ & $22.79 \pm 1.91$ & $2.33 \mathrm{NS}$ \\
\hline Protein (g) & $5.7 \pm 0.1$ & $6.02 \pm 0.14$ & $3.22 \mathrm{NS}$ \\
\hline Fat (g) & $12.45 \pm 0.5$ & $13 \pm 0.5$ & $1.54 \mathrm{NS}$ \\
\hline Total minerals (g) & $2.4 \pm 1.75$ & $2.47 \pm 0.02$ & $0.05 \mathrm{NS}$ \\
\hline fibre $(\mathrm{g})$ & $0.75 \pm 0.15$ & $0.95 \pm 0.2$ & $1.13 \mathrm{NS}$ \\
\hline Carbohydrates (g) & $78.7 \pm 1.65$ & $79.09 \pm 2$ & $0.21 \mathrm{NS}$ \\
\hline Calcium (mg) & $65 \pm 5$ & $157 \pm 20$ & $6.31 * *$ \\
\hline Iron (mg) & $4.38 \pm 0.002$ & $4.43 \pm 0.02$ & $3.51 *$ \\
\hline Copper (mg) & $0.88 \pm 0.02$ & $0.75 \pm 0.05$ & $3.41 *$ \\
\hline Zinc (mg) & $1.42 \pm 0.03$ & $1.54 \pm 0.05$ & $2.91 \mathrm{NS}$ \\
\hline Manganese (mg) & $1.30 \pm 0.005$ & $1.43 \pm 0.03$ & $6.08 * *$ \\
\hline
\end{tabular}

NS: Non significant; *Significant at 5 per cent; **Significant at 1 per cent

Table.5 Mean scores for overall acceptability of Colocasia kharapara stored in zip lock bag and aluminium foil for varying periods

\begin{tabular}{|c|c|c|c|}
\hline \multirow[t]{2}{*}{$\begin{array}{l}\text { Storage period } \\
\text { (Days) }\end{array}$} & \multicolumn{2}{|c|}{$\begin{array}{c}\text { Mean scores for overall acceptability for Colocasia } \\
\text { kharapara }\end{array}$} & \multirow[t]{2}{*}{ 't' value } \\
\hline & $\begin{array}{c}\text { Zip lock bag } \\
\text { Mean } \pm \text { SD }\end{array}$ & $\begin{array}{l}\text { Aluminium foil } \\
\text { Mean } \pm \text { SD }\end{array}$ & \\
\hline 1 & $4.93 \pm 0.25$ & $4.93 \pm 0.25$ & $0.000^{\mathrm{NS}}$ \\
\hline 7 & $4.73 \pm 0.45$ & $4.80 \pm 0.41$ & $1.146^{\mathrm{NS}}$ \\
\hline 14 & $3.73 \pm 0.59$ & $4.13 \pm 0.51$ & $0.323^{\mathrm{NS}}$ \\
\hline 21 & $3.40 \pm 0.50$ & $3.53 \pm 0.51$ & $1.784^{\mathrm{NS}}$ \\
\hline 28 & $2.93 \pm 0.45$ & $3.46 \pm 0.74$ & $1.169^{\mathrm{NS}}$ \\
\hline $\mathrm{CD}$ & 0.342 & 0.376 & \\
\hline $\mathrm{SE} \pm$ & 0.121 & 0.133 & \\
\hline F-value & $50.73 * *$ & $26.64 * *$ & \\
\hline
\end{tabular}

NS: Non significant

Table.6 Mean score for overall acceptability of colocasia puri stored in zip lock bag and aluminium foil for varying periods

\begin{tabular}{|c|c|c|c|}
\hline \multirow{2}{*}{$\begin{array}{l}\text { Storage period } \\
\text { (Days) }\end{array}$} & \multicolumn{2}{|c|}{ Mean score for overall acceptability for Colocasia puri } & \multirow[t]{2}{*}{ 't' value } \\
\hline & $\begin{array}{c}\text { Zip lock bag } \\
\text { Mean } \pm \text { SD }\end{array}$ & $\begin{array}{c}\text { Aluminium foil } \\
\text { Mean } \pm \text { SD }\end{array}$ & \\
\hline 1 & $4.93 \pm 0.25$ & $4.93 \pm 0.25$ & $0.000^{\mathrm{NS}}$ \\
\hline 2 & $4.60 \pm 0.41$ & $4.80 \pm 0.41$ & $1.146^{\mathrm{NS}}$ \\
\hline 3 & $4.33 \pm 0.51$ & $4.40 \pm 0.50$ & $0.323^{\mathrm{NS}}$ \\
\hline 4 & $3.60 \pm 0.51$ & $3.93 \pm 0.45$ & $1.784^{\mathrm{NS}}$ \\
\hline 5 & $3.467 \pm 0.74$ & $3.73 \pm 0.59$ & $1.169^{\mathrm{NS}}$ \\
\hline CD & 0.362 & 0.336 & \\
\hline $\mathrm{SE} \pm$ & 0.128 & 0.119 & \\
\hline F- value & $24.60^{* *}$ & $19.48 * *$ & \\
\hline
\end{tabular}

NS: Non significant 
It can be said that addition of dry colocasia leaves powder up to 7 per cent in kharapara did not affect sensory qualities except texture of colocasia kharapara. Colocasia leaves powder was incorporated in khqarapara up to 7 per cent level (Table 1). The results revealed that colocasia leaves powder incorporation up to 7 per cent in kharapara was increased in nutrient content significantly in calcium, and copper content (Table 3). Colocasia kharapara stored in zip lock bag and aluminium foil for 28 days. Overall acceptability scores of Colocasia kharapara stored for 28 days in zip lock bag and aluminium foil did not differ significant. Kharapara is a deep fried product so can be kept for more days but some rancid flavour may develop with storage (Table 5).

Puri prepared with various levels (up to 7 per cent) of incorporation and without incorporation of colocasia leaves powder, when subjected to organoleptic evaluation indicated that 6 per cent incorporation of colocasia leaves was well accepted by panel members (Table 2). Puri with addition of colocasia leaves powder showed that significant increase in values of nutrients such as calcium, iron and manganese. Other nutrients were numerically increased (Table 4). Colocasia puri was stored for five days in zip lock bag and aluminum foil. It was noticed that scores of colocasia puri for overall acceptability was good up to 3 days there after the scores decreased. The colocasia puri may be kept in aluminium foil up to five days (Table 6).

It is concluded from this study that dry colocasia leaves powder up to 6 to 7 per cent for value addition of different products. Colocasia leaves are rich in calcium so the calcium content of the products will be increased and will be useful to combat calcium deficiency. Colocasia leaves are also rich in minerals like iron, copper, zinc and manganese, so the addition of colocasia leaves will be helpful to cure micronutrient deficiencies.

\section{References}

A.O.A.C. (1984). Official methods of analysis. Association of Official Analytical Chemist. $\quad 14^{\text {th }} \quad$ Ed. Washington DC.

Abuajah, C. I., Ogbonna, A.C., and Osuji, C. M. (2015). Functional components and medical properties of food: A review. Journal of Food Science and Technology, 52 (5), 2522-2529.

Amerine, M. A., Pongborn R.M. and Roessler E.D. (1965). Principles of sensory evaluation of foods. Academic Press, New York.

Aregheore, E., and Perera, D. (2003). Dry matter, nutrient composition and palatability/acridity of eight exotic cultivars of cocoyams-taro (Colocasia esculenta) in Samoa. Plant Foods for Human Nutrition, 58, 1-8.

Chay-Prove, P. and Goebel, R. (2004). Taro: the plant. Department of Primary Industries and Fisheries Note. Queensland Government Australia. Available from www.dpi.qld.gov.au/ horticulture.

FAO (1992). Taro: a south Pacific specialty. Leaflet - revised 1992. Community Health Services, South Pacific Commission, B.P. D5, Noumea, Cedex, New Caledonia.

Fellows P. (1990). Food Processing Technology: Principles and Practice. West Sussex, England. Ellis Horwood Limited, pp. 31-35, 197-208.

Gopalan, C., Rama Sastri, B. V. R, and Balsubramaniam, S. C. (1989). Nutritive value of Indian foods, National Institute of Nutrition (ICMR) Hyderabad, pp, 49. 
Gupta S.P. (2014). Statistical Methods. Sultan Chand and Son Publication.

Lewu, M. N., Adebola, P. O. and Afolayan, A. J. (2009). Effect of cooking on the proximate composition of the leaves of some accessions of Colocasia esculenta (L) Schott in KwaZulu- Natal province of South Africa. African Journal of Biotechnology Vol.8 (8), 1619-1622.

Malese, T. and Negussie, R. (2015) Nutritional Potential, Health and Food Security Benefits of Taro. Food Science and Quality Management Vol. 36, 2330 .

Matthews, P. (2004). Genetic diversity in taro, and the preservation of culinary knowledge. Ethnobotany Journal, 2(1547), 55-77.

Ndabikunze B. K. Talwana H.A.L. Mongi R. D. Issa-Zacharia A; Serem A. K, Palapala V. and Nandi D.O.M (2011). Proximate and Mineral Composition (Colocasia esculenta \& $X$. Sagittifolium) (online) Available at: http://www.acdemicmicjournal.org/ajfs/
Abstract 2011/Ndabiku/20/alhtm. accessed on $2^{\text {nd }} /$ Dec./2011.

Njintang, N. Y., M. F. Mbofung and R. Kesteloot, (2007). Multivariate analysis of the effect of drying method and particle size of flour on the instrumental texture characteristics of paste made from two variates of taro flour. Journal of Food Engineering 58:259-265.

Patricia, R. P., Joab, T. S., Mauricio. A. V., Vania M. F. P. and Gerlinde A. P. B. T. (2015). Crude extract from taro as a natural source of bioactive proteins able to stimulate haematopoietic cell in two murine models. Journal of Functional Foods Vol.18: 333-343.

Ranganna S. (1979). Titrable acidity. In: Ranganna, S. (Ed). Manual of Analysis of Fruit and Vegetable products. Pp. 7 8. Tata McGraw Hill Publishing Company Ltd., New Delhi, India

Savage, G. P. and Dubois, M. (2006). The effect of soaking and cooking on the oxalate content of taro leaves. International Journal of Food Science and Nutrition vol. 57 (5/6), 376-381.

\section{How to cite this article:}

Pratibha Thombare and Farooqui H. Farzana. 2018. Organoleptic Evaluation of Dried Colocasia Leaves (Colocasia esculenta) Powder Incorporated in Kharapara and Puri. Int.J.Curr.Microbiol.App.Sci. 7(11): 2844-2850. doi: https://doi.org/10.20546/ijcmas.2018.711.327 